\title{
Understanding Chlorite and Chlorate Formation Associated with Hypochlorite Generation at Boron Doped Diamond Film Anodes
}

\author{
D. K. Hubler, ${ }^{a}$ J. C. Baygents, ${ }^{a}$ B. P. Chaplin, ${ }^{b}$ and J. Farrell ${ }^{\text {a,z }}$ \\ ${ }^{a}$ Department of Chemical and Environmental Engineering, University of Arizona, Tucson, Arizona 85721, USA \\ ${ }^{b}$ Department of Chemical Engineering, University of Illinois at Chicago, Chicago, Illinois 60607, USA
}

\begin{abstract}
This research investigated reaction pathways for formation of chlorite and chlorate when using boron doped diamond (BDD) film anodes for generating hypochlorite. Batch electrolysis and voltammetry experiments were performed to investigate the rates and potential dependency of hypochlorite and chlorite oxidation. Density functional theory (DFT) modeling was used to investigate possible reaction pathways. The DFT simulations included reactions with hydrogen terminated surfaces, and with surface sites produced by anodic polarization, namely: $\equiv \mathrm{C}^{\bullet},=\mathrm{C}^{\bullet} \mathrm{H}, \equiv \mathrm{C}-\mathrm{O}^{\bullet}$ and $=\mathrm{C}^{\bullet} \mathrm{HO}$. Oxychlorine radicals $\left(\mathrm{ClO}^{\bullet}, \mathrm{ClO}_{2}{ }^{\bullet}\right)$ were found to chemically adsorb to both secondary and tertiary carbon atoms on the BDD surface. These chemisorbed intermediates could react with hydroxyl radicals to regenerate the original chlorine oxyanion $\left(\mathrm{ClO}^{-}\right.$or $\left.\mathrm{ClO}_{2}^{-}\right)$, and produce $\equiv \mathrm{C}-\mathrm{O}^{\bullet}$ and $=\mathrm{C}^{\bullet} \mathrm{HO}$ sites on the $\mathrm{BDD}$ surface. The $\equiv \mathrm{C}-\mathrm{O}^{\bullet}$ and $=\mathrm{C}^{\bullet} \mathrm{HO}$ sites also reacted with oxychlorine radicals to form chemisorbed intermediates, which could then be converted to higher oxidation states $\left(\mathrm{ClO}_{2}{ }^{-}, \mathrm{ClO}_{3}{ }^{-}\right)$via reaction with hydroxyl radicals. The predominant pathway for chlorite and chlorate production appears to involve oxidation of $\mathrm{HOCl}$ or $\mathrm{HClO}_{2}$ via direct electron transfer, followed by reaction of $\mathrm{ClO}^{\bullet}$ or $\mathrm{ClO}_{2} \bullet$ with a hydroxyl radical.

(c) 2014 The Electrochemical Society. [DOI: 10.1149/2.1001412jes] All rights reserved.
\end{abstract}

Manuscript submitted July 15, 2014; revised manuscript received September 2, 2014. Published September 17, 2014. This was Paper 247 presented at the San Francisco, California, Meeting of the Society, October 27-November 1, 2013.

The use of boron-doped diamond (BDD) film electrodes in water treatment applications is increasing due to their chemical stability and effectiveness in oxidizing a wide variety of organic and inorganic compounds. The oxidizing power of BDD anodes is directly related to their high overpotential for oxygen evolution. ${ }^{1}$ This feature allows BDD anodes to be polarized to high anodic potentials in aqueous systems while still maintaining high faradaic current efficiencies for target compound oxidation. Oxidation of compounds by BDD anodes has been found to occur via both direct electron transfer and via hydroxyl radicals $\left(\mathrm{HO}^{\bullet}\right)$ generated from water oxidation. ${ }^{2-7}$

One proposed use of BDD anodes is for on-site generation of hypochlorite for use as a disinfectant in recirculating cooling systems, drinking water, or swimming pool applications. ${ }^{8}$ This process utilizes stable anode materials to oxidize chloride ions $\left(\mathrm{Cl}^{-}\right)$to hypochlorite ions $\left(\mathrm{OCl}^{-}\right)$and hypochlorous acid $(\mathrm{HOCl})$. However, several studies have found significant quantities of chlorate $\left(\mathrm{ClO}_{3}{ }^{-}\right)$and perchlorate $\left(\mathrm{ClO}_{4}^{-}\right)$may be produced when chloride containing solutions are electrolyzed. ${ }^{9,10}$ All chlorine oxyanions have been detected in electrolyzed chloride solutions, including $\mathrm{OCl}^{-}$, chlorite $\left(\mathrm{ClO}_{2}{ }^{-}\right)$, $\mathrm{ClO}_{3}{ }^{-}$and $\mathrm{ClO}_{4}{ }^{-}$. Batch experiments show that complete conversion of $\mathrm{Cl}^{-}$to $\mathrm{ClO}_{4}{ }^{-}$can be achieved with prolonged electrolysis times. ${ }^{10}$ Perchlorate production can be minimized in batch and flow-through systems by using low current densities, high mass transfer rates, and high concentrations of chloride. ${ }^{10}$ High mass transfer rates, driven by fluid convection, has been suggested to affect the multistep reaction for $\mathrm{ClO}_{4}^{-}$formation from $\mathrm{Cl}^{-}$, as $\mathrm{Cl}^{-}$ions are progressively oxidized to higher oxychlorine anions, as illustrated by:

$$
\underset{\text { chloride }}{\mathrm{Cl}^{-}} \rightarrow \underset{\text { hypochlorite }}{\mathrm{OCl}^{-}} \rightarrow \underset{\text { chlorite }}{\mathrm{ClO}_{2}^{-}} \rightarrow \underset{\text { chlorate }}{\mathrm{ClO}_{3}^{-}} \rightarrow \underset{\text { perchlorate }}{\mathrm{ClO}_{4}^{-}}
$$

High rates of mass transfer near the anode surface result in low concentrations of intermediate products, so that complete chloride oxidation to perchlorate can be minimized.

The production of $\mathrm{ClO}_{4}{ }^{-}$during electrolysis is problematic due to its carcinogenic potential and its adverse effects on thyroid gland function. ${ }^{11,12}$ These health risks have prompted the United States Environmental Protection Agency to issue an advisory target of $15 \mu \mathrm{g} / \mathrm{L}$ for perchlorate in drinking water sources. ${ }^{13}$ Furthermore, two states, California and Massachusetts, have mandated even lower drinking water limits for perchlorate of 6 and $2 \mu \mathrm{g} / \mathrm{L}$, respectively. ${ }^{14,15}$

Kinetic studies have shown that the rate-determining step in $\mathrm{ClO}_{4}{ }^{-}$ formation is the oxidation of $\mathrm{ClO}_{3}{ }^{-}$to $\mathrm{ClO}_{4}{ }^{-} \cdot$. Azizi et al. used molecular modeling and batch experimental studies and determined

${ }^{\text {z} E-m a i l: ~ f a r r e l l j @ e m a i l . a r i z o n a . e d u ~}$ that the mechanism of $\mathrm{ClO}_{4}{ }^{-}$formation on $\mathrm{BDD}$ anodes is a two-step process. ${ }^{16}$ The first step involves the direct oxidation of $\mathrm{ClO}_{3}{ }^{-}$to form $\mathrm{ClO}_{3}{ }^{\bullet}$, and the second step involves reaction of $\mathrm{ClO}_{3}{ }^{\bullet}$ with $\mathrm{OH}^{\bullet}$ to form $\mathrm{HClO}_{4}{ }^{16}$ While these studies helped elucidate the mechanism for $\mathrm{ClO}_{4}{ }^{-}$formation from $\mathrm{ClO}_{3}{ }^{-}$, mechanistic understanding of the pathways responsible for $\mathrm{ClO}_{3}{ }^{-}$formation is lacking.

The goal of this research was to develop plausible reaction pathways for oxidizing $\mathrm{HOCl}$ and $\mathrm{OCl}^{-}$to form $\mathrm{HClO}_{3}$ and $\mathrm{ClO}_{3}{ }^{-}$at $\mathrm{BDD}$ anodes. Towards that end, batch electrolysis experiments, linear sweep and cyclic voltammetry, and density functional theory (DFT) simulations were conducted. Direct electron transfer reactions were modeled for generating hydroxyl $\left(\mathrm{HO}^{\bullet}\right)$ and $\mathrm{ClO}_{\mathrm{x}}{ }^{\bullet}$ radicals. Additionally, reactions of these species with each other and with sites on the $\mathrm{BDD}$ surface were investigated. Mechanisms in which $\mathrm{ClO}_{\mathrm{x}}{ }^{\bullet}$ radicals chemisorb to the anode surface were also considered, and several reaction pathways between $\mathrm{HOCl} / \mathrm{OCl}^{-}$and $\mathrm{HClO}_{3} / \mathrm{ClO}_{3}{ }^{-}$were elucidated. This information will be useful in developing mathematical models for electrochemical cells used for producing hypochlorite from chloride solutions.

\section{Materials and Methods}

Reagents. - All chemicals were reagent grade and obtained from Fisher Scientific or Sigma Aldrich. Chemicals were used as received without additional purification. Solutions were made from Milli-Q Ultrapure water $\left(18.2 \mathrm{M} \Omega-\mathrm{cm}\right.$ at $\left.21^{\circ} \mathrm{C}\right)$.

Electrodes.- All electrodes used were ultrananocrystalline BDD films on p-silicon substrates (Advanced Diamond Technologies, Romeoville, IL). The BDD films were deposited by chemical vapor deposition and grown to a thickness of approximately $2 \mu \mathrm{m}$ using 750-12000 parts-per-million of trimethyl borane in flowing $\mathrm{CH}_{4}$ at temperatures between $700-800^{\circ} \mathrm{C}$. As prepared BDD films had measured resistivities between $0.05-0.1 \mathrm{ohm}-\mathrm{cm}$.

Voltammetry.- Linear sweep voltammetry (LSV) and cyclic voltammetry $(\mathrm{CV})$ experiments at a scan rate of $100 \mathrm{mV} / \mathrm{s}$ were conducted to determine the potentials at which several chlorine oxyanions underwent direct electron transfer reactions at the BDD surface. Experiments were conducted using a $0.35 \mathrm{~cm}^{2}$ BDD electrode, a $12 \mathrm{~cm}$ long by $0.3 \mathrm{~mm}$ diameter $\mathrm{Pt}$ wire counter electrode, and a $\mathrm{Hg} / \mathrm{HgSO}_{4}$ reference electrode saturated with $\mathrm{K}_{2} \mathrm{SO}_{4}$. Currents and electrode potentials were controlled and measured using a Gamry Reference 600 potentiostat/galvanostat (Warminster, PA). Potentials are reported versus the standard hydrogen electrode (SHE). 
Batch oxidation experiments. - Reaction rates for $\mathrm{ClO}_{2}{ }^{-}$oxidation were measured at constant anodic potentials using a rotating disk electrode (RDE), rotated at 6000 revolutions per minute to eliminate mass transfer effects on the measured reaction rates. Experiments were performed over a temperature range of 10 to $40^{\circ} \mathrm{C}$ using a recirculating water bath (Thermo Electron Corp., Neslab RTE7). Batch oxidation experiments utilized the electrode setup described for voltammetry experiments. However, batch experiments used a Nafion N115 membrane (Ion Power, Inc., New Castle, DE) to separate the anode and cathode compartments of the cell in order to isolate the anodic reactions. Starting $\mathrm{ClO}_{2}{ }^{-}$concentrations of $1 \mathrm{mM}$ in a $100 \mathrm{mM} \mathrm{KH} \mathrm{PO}_{4}$ background electrolyte were used.

Analytical methods. - Concentrations of $\mathrm{ClO}_{2}{ }^{-}$and $\mathrm{ClO}_{3}{ }^{-}$were determined by ion chromatography (Dionex ICS-3000; Dionex IonPac AS16 column; $\mathrm{KOH}$ eluant; $1 \mathrm{~mL} / \mathrm{min}$ eluant flow rate). Free available chlorine concentrations were measured using Hach method 8021. An Accumet model $25 \mathrm{pH}$ probe was used to measure the solution $\mathrm{pH}$.

Simulation clusters. - Two different molecular clusters were used to model the diamond electrode surface: a previously described 10carbon atom cluster, ${ }^{16,17}$ shown in Figure 1a, and a previously described 34-carbon atom cluster with a central boron atom, ${ }^{18,19}$ shown in Figure 1b. These structures contain three distinct types of surface sites, labeled as $\equiv \mathrm{CH},=\mathrm{CH}_{2}$, and $\mathrm{B} \equiv \mathrm{CH}$.

In addition to simulations using hydrogen-terminated structures, simulations were also performed with functional groups produced by anodic polarization. Freshly prepared BDD surfaces are terminated with hydrogen atoms. ${ }^{1,20-22}$ However, anodic polarization results in oxidation of the surface to produce carboxyl $(\equiv \mathrm{C}-\mathrm{OH})$, carbonyl $(=\mathrm{C}=\mathrm{O})$, and aldehyde $(=\mathrm{CHO})$ functional groups. These functional groups have a major effect on the physical, chemical and electronic characteristics of the BDD surface, and impact the mechanism of both anodic and cathodic reactions. ${ }^{16,17}$ These functional groups may also become oxidized themselves under anodic polarization, and anodically polarized BDD surfaces are believed to contain carbon radical $\left(\equiv \mathrm{C}^{\bullet}\right)$, carboxyl radical $\left(\equiv \mathrm{C}-\mathrm{O}^{\bullet}\right)$, and aldehyde radical $\left(=\mathrm{CH}-\mathrm{O}^{\bullet}\right)$ functional groups. ${ }^{19}$

Density functional theory (DFT) modeling.- All DFT calculations were performed with the DMol3 package in the Accelrys Materials Studio modeling suite on a personal computer. ${ }^{23-25}$ All simulations used double-numeric with polarization (DNP) basis sets and the gradient-corrected Becke-Lee-Yang-Parr (BLYP) functionals for exchange and correlation. ${ }^{26-28}$ The nuclei and core electrons were described by DFT optimized semilocal pseudopotentials. ${ }^{29}$ Implicit solvation was incorporated into all simulations by use of the COSMO-ibs polarizable continuum model. ${ }^{30}$ Thermal smearing of 0.005 Ha was used to facilitate numerical convergence. The reaction energies $(\Delta E)$ presented here represent the $0 \mathrm{~K}$ reaction energies without thermal or zero-point corrections. These corrections are small $(<4 \mathrm{~kJ} / \mathrm{mol})$

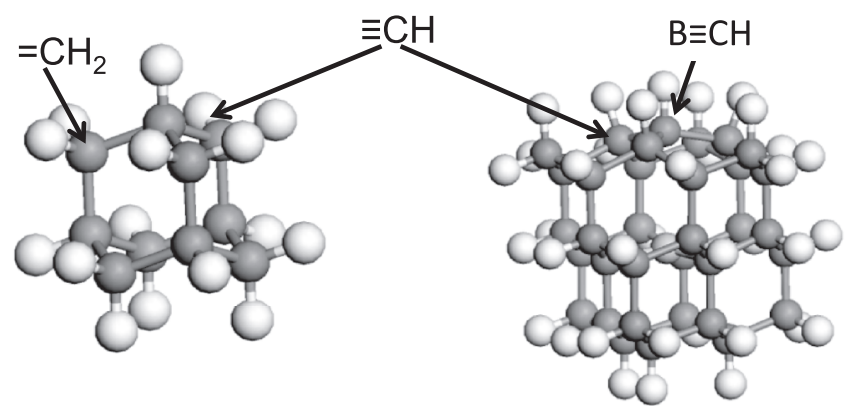

Figure 1. a) 10-carbon structure used for simulating the diamond surface. The structure is $\mathrm{C}_{10} \mathrm{H}_{16}$; b) 34-carbon structure used for simulating boron-doped sites near the diamond surface. The structure is $\mathrm{C}_{34} \mathrm{BH}_{36}$, and the $\mathrm{B} \equiv \mathrm{CH}$ site is indicated. Atom key: carbon, gray; hydrogen, white; boron, pink. and are less than the errors in the calculation of the reaction energies themselves, which may be up to $16 \mathrm{~kJ} / \mathrm{mol}^{31}$

The activation energies $\left(E_{\mathrm{a}}\right)$ for direct electron transfer as a function of the electrode potential were calculated by the method of Anderson and Kang. ${ }^{18,32}$ Reactant energies were calculated as a function of the reaction coordinate, defined as the bond length of the bond that was formed or broken during the reaction. Product energies were calculated using the atomic positions determined from the optimized reactant structures, followed by self-consistent field optimization of the electronic configurations. The energy of the free electron on the vacuum scale was adjusted to the standard hydrogen electrode (SHE) scale by subtracting $4.6 \mathrm{eV},{ }^{32}$ Product energies were adjusted to reflect the electrode potential by shifting the energy profile of the product species downwards by $96.5 \mathrm{~kJ} / \mathrm{mol}$ (i.e., $1.0 \mathrm{eV}$ ) to increase the electrode potential by $1.0 \mathrm{~V}$ and upwards by $96.5 \mathrm{~kJ} / \mathrm{mol}$ to decrease the electrode potential by $1.0 \mathrm{~V}$. Intersection of the product and reactant energy profiles yields the bond length of transition state and the activation energy for the reaction. ${ }^{32}$ Simulations involving solvated protons included two explicit water molecules to more accurately mimic physical reality. ${ }^{33}$

\section{Results and Discussion}

Chlorite formation.- LSV experiments were performed to determine the potential at which $\mathrm{HOCl}$ and $\mathrm{OCl}^{-}$were oxidized at the BDD surface. Figure 2 shows LSV scans with varying concentrations of $\mathrm{HOCl}$ in a $1 \mathrm{M} \mathrm{KH}_{2} \mathrm{PO}_{4}$ background electrolyte $(\mathrm{pH}=4.5)$. Increased concentrations of $\mathrm{HOCl}$ showed increased anodic current at potentials $>1.7 \mathrm{~V} / \mathrm{SHE}$. This indicates that there is oxidation of $\mathrm{HOCl}$ via direct electron transfer to the BDD surface. These results also show that $\mathrm{HOCl}$ is oxidized at lower potentials than water. Similar experiments were also performed at an alkaline $\mathrm{pH}$ of 11.3 in a $1 \mathrm{M} \mathrm{NaClO}_{4}$ electrolyte in order to observe if the deprotonated $\mathrm{OCl}^{-}$species also underwent direct electron transfer. The LSV scans shown in Figure 3 indicate that $\mathrm{OCl}^{-}$is oxidized at lower potentials than $\mathrm{HOCl}$, as indicated by the increased anodic current observed in the presence of $\mathrm{OCl}^{-}$at potentials $>1.5 \mathrm{~V} / \mathrm{SHE}$. Once again these results indicate that $\mathrm{OCl}^{-}$is oxidized at lower potentials than water oxidation, via a direct electron transfer reaction.

Linear sweep voltammetry scans were also performed in a $1 \mathrm{M}$ $\mathrm{NaCl}$ background electrolyte with varying amounts of $\mathrm{OCl}^{-}$to assess if surface site competition existed between $\mathrm{OCl}^{-}$and $\mathrm{Cl}^{-}$. The data in Figure 4 shows that $\mathrm{OCl}^{-}$oxidation occurs at approximately the same potential as shown in Figure 3 with the $\mathrm{NaClO}_{4}$ electrolyte $(\sim 1.5$ V/SHE), which corresponds to lower potentials than are necessary to oxidize $\mathrm{Cl}^{-}$. Based on these results, it is expected that oxidation of $\mathrm{HOCl} / \mathrm{OCl}^{-}$will occur at the potentials present during hypochlorite production from $\mathrm{Cl}^{-}$solutions.

The reaction mechanisms responsible for the observations in Figures 2-4 were investigated using DFT simulations. Since BDD anodes are known to generate hydroxyl radicals, reactions of $\mathrm{HO}^{\bullet}$ 


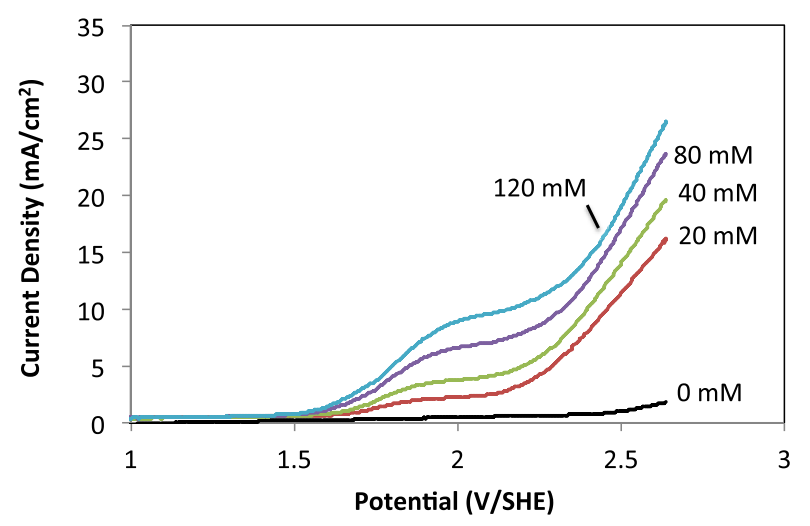

Figure 3. Linear sweep voltammetry scans in $1 \mathrm{M} \mathrm{NaClO}_{4}$ with varying concentrations of $\mathrm{OCl}^{-}$at $\mathrm{pH}=11.3$; Scan rate $=100 \mathrm{mV} \mathrm{s}^{-1} ; \mathrm{T}=22^{\circ} \mathrm{C}$.

with $\mathrm{OCl}^{-}$and $\mathrm{HOCl}$ in homogeneous solution were also considered. The $\mathrm{HClO}_{2}^{-}$structure formed by reacting $\mathrm{HO}^{-}$with $\mathrm{OCl}^{-}$ was found to be unstable, suggesting this reaction does not occur. However, it was found that a $\mathrm{HO}^{*}$ radical was able to abstract a $\mathrm{H}$ atom from $\mathrm{HOCl}$ to produce the $\mathrm{OCl}^{\bullet}$ species, as shown in reaction 2:

$$
\mathrm{HOCl}+\mathrm{HO}^{\bullet} \rightarrow \mathrm{OCl}^{\bullet}+\mathrm{H}_{2} \mathrm{O}
$$

DFT calculations indicate that this reaction is activationless and has a reaction energy of $\Delta E=-127 \mathrm{~kJ} / \mathrm{mol}$. The hypochlorite radical $\left(\mathrm{OCl}^{\bullet}\right)$ formed in reaction 2 may also be produced via a direct electron transfer reaction between $\mathrm{HOCl}$ and the electrode via reaction 3:

$$
\mathrm{HOCl} \rightarrow[\mathrm{HOCl}]^{+}+e^{-} \rightarrow \mathrm{OCl}^{\bullet}+\mathrm{H}^{+}+e^{-}
$$

Figure 5 shows the activation energy for reaction 3 as a function of electrode potential. Calculations indicate that at room temperature this reaction should begin to occur at measurable rates at potentials above $\sim 1.9 \mathrm{~V} / \mathrm{SHE}$ (where the $E_{\mathrm{a}}$ drops below $40 \mathrm{~kJ} / \mathrm{mol}$ ), and the reaction is activationless at potentials $>2.36 \mathrm{~V} / \mathrm{SHE}$. These modeling results compare well with the LSV results in Figure 2, which showed increased current due to direct electron transfer from $\mathrm{HOCl}$ to the BDD surface at potentials $>1.7 \mathrm{~V} / \mathrm{SHE}$. DFT calculations for the oxidation of water to form $\mathrm{HO}^{\bullet}$ is also shown in Figure 5. The greater activation barriers for direct $\mathrm{H}_{2} \mathrm{O}$ versus $\mathrm{HOCl}$ oxidation agree with the LSV scans which show that $\mathrm{HOCl}$ oxidation occurs at lower potentials than $\mathrm{H}_{2} \mathrm{O}$ oxidation. This means that the direct electron transfer pathway to produce $\mathrm{OCl}^{\bullet}$ radicals (reaction 3) can occur at lower potentials than the chemical pathway (reaction 2).

Both $\mathrm{HO}^{\bullet}$ and $\mathrm{OCl}^{\bullet}$ radicals are present in the solution near the electrode surface, so the combination of the two radicals to form

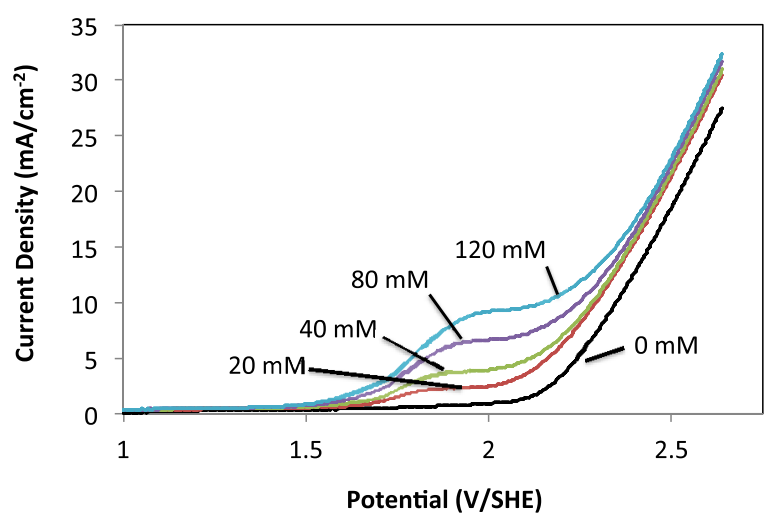

Figure 4. Linear sweep voltammetry scans in $1 \mathrm{M} \mathrm{NaCl}$ with varying concentrations of $\mathrm{OCl}^{-}$at $\mathrm{pH}=11.3$; $\mathrm{Scan}$ rate $=100 \mathrm{mV} \mathrm{s}^{-1} ; \mathrm{T}=22^{\circ} \mathrm{C}$.

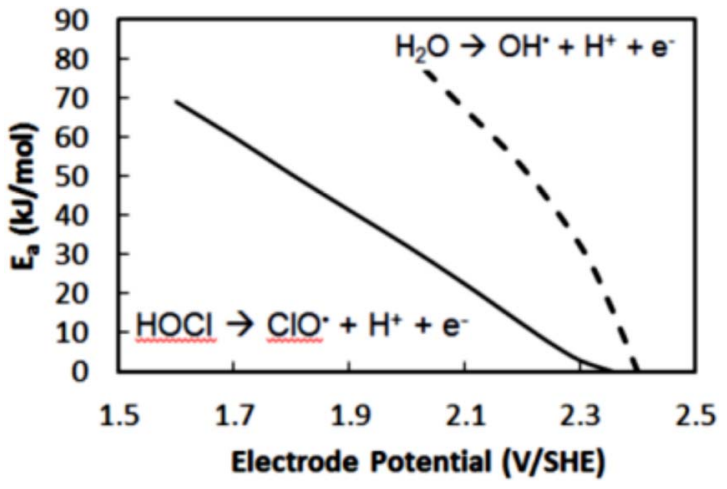

Figure 5. Activation energy as a function of electrode potential for direct electron transfers from $\mathrm{HOCl}$ (reaction 3) and $\mathrm{H}_{2} \mathrm{O}$.

$\mathrm{HClO}_{2}$ was considered, as shown in reaction 4:

$$
\mathrm{OCl}^{\bullet}+\mathrm{HO}^{\bullet} \rightarrow \mathrm{HClO}_{2}
$$

Reaction 4 is activationless with a reaction energy $\Delta E$ $=-90 \mathrm{~kJ} / \mathrm{mol}$. Reactions $2-4$ provide two plausible pathways that explain $\mathrm{HClO}_{2}$ production from $\mathrm{HOCl}$.

Additional DFT simulations were conducted to investigate the role of oxidized surface sites in the production of $\mathrm{ClO}_{2}{ }^{-}$on the 10- and 34carbon atom clusters shown in Figure 1. These simulations considered the interaction of $\mathrm{OCl}^{\bullet}$ with four oxidized surface sites, shown across the top of Figure 6 for the 10-carbon atom cluster and two oxidized surface sites shown across the top of Figure 7 for the boron-containing cluster.

The $\equiv \mathrm{C}^{\bullet}$ and $\equiv \mathrm{C}-\mathrm{O}^{\bullet}$ sites shown in Figure $6 \mathrm{a}$ and Figure $6 \mathrm{c}$, respectively, are $s p^{3}$ carbon radical sites in which the surficial carbon atom has bonds to three other carbon atoms. The $=\mathrm{C}^{\bullet} \mathrm{H}$ site and $\equiv \mathrm{CH}-\mathrm{O}^{\bullet}$ sites shown in Figure $6 \mathrm{~b}$ and Figure 6d, respectively, contain a surficial carbon atom with bonds to two other carbon atoms and are $s p^{2}$ in character. These functional groups may occur at crystal edges or in defect sites on the polycrystalline BDD surface.

Figure 6a illustrates a two-step reaction scheme for oxidation of a $\equiv \mathrm{C}^{\bullet}$ site in the presence of $\mathrm{OCl}^{\bullet}$ and $\mathrm{HO}^{\bullet}$ radicals:

$$
\begin{gathered}
\equiv \mathrm{C}^{\bullet}+\mathrm{OCl}^{\bullet} \rightarrow \equiv \mathrm{C}-\mathrm{OCl} \\
\equiv \mathrm{C}-\mathrm{OCl}+\mathrm{HO}^{\bullet} \rightarrow \equiv \mathrm{C}-\mathrm{O}^{\bullet}+\mathrm{HOCl}
\end{gathered}
$$

Both reactions are activationless, with $\Delta E=-195 \mathrm{~kJ} / \mathrm{mol}$ for reaction 5 and $\Delta E=-95 \mathrm{~kJ} / \mathrm{mol}$ for reaction 6.

Figure $6 \mathrm{~b}$ illustrates a two-step reaction scheme for oxidation of a $=\mathrm{C}^{\bullet} \mathrm{H}$ edge site in the presence of $\mathrm{OCl}^{\bullet}$ and $\mathrm{HO}^{\bullet}$ radicals:

$$
\begin{gathered}
=\mathrm{C}^{\bullet} \mathrm{H}+\mathrm{OCl}^{\bullet} \rightarrow=\mathrm{CH}-\mathrm{OCl} \\
=\mathrm{CH}-\mathrm{OCl}+\mathrm{HO}^{\bullet} \rightarrow=\mathrm{CH}-\mathrm{O}^{\bullet}+\mathrm{HOCl}
\end{gathered}
$$

Both steps are activationless, with $\Delta E=-208 \mathrm{~kJ} / \mathrm{mol}$ for reaction 7 and $\Delta E=-103 \mathrm{~kJ} / \mathrm{mol}$ for reaction 8 . These results indicate that it is possible that a certain fraction of $\mathrm{OCl}^{\bullet}$ produced at the anode surface may revert back to $\mathrm{HOCl}$, which is consistent with prior DFT calculations that indicated it was thermodynamically feasible for $\mathrm{ClO}_{3}{ }^{\bullet}$ radicals to react with $\mathrm{BDD}$ surface sites to produce $\mathrm{ClO}_{3}{ }^{-} .{ }^{16}$

Once oxidized, the BDD sites may catalyze $\mathrm{HClO}_{2}$ production. Figure $6 \mathrm{c}$ shows a two-step reaction scheme for $\mathrm{HClO}_{2}$ production at $\mathrm{a} \equiv \mathrm{C}-\mathrm{O}^{\bullet}$ site:

$$
\begin{gathered}
\equiv \mathrm{C}-\mathrm{O}^{\bullet}+\mathrm{OCl}^{\bullet} \rightarrow \equiv \mathrm{C}-\mathrm{O}-\mathrm{COl} \\
\equiv \mathrm{C}-\mathrm{O}-\mathrm{ClO}+\mathrm{HO}^{\bullet} \rightarrow=\mathrm{C}-\mathrm{O}^{\bullet}+\mathrm{HClO}_{2}
\end{gathered}
$$

The chemisorption reaction is activationless with an energy change of $\Delta E=-49 \mathrm{~kJ} / \mathrm{mol}$ for reaction 9 . The subsequent oxidation step (reaction 10), has an activation energy of $12 \mathrm{~kJ} / \mathrm{mol}$ 


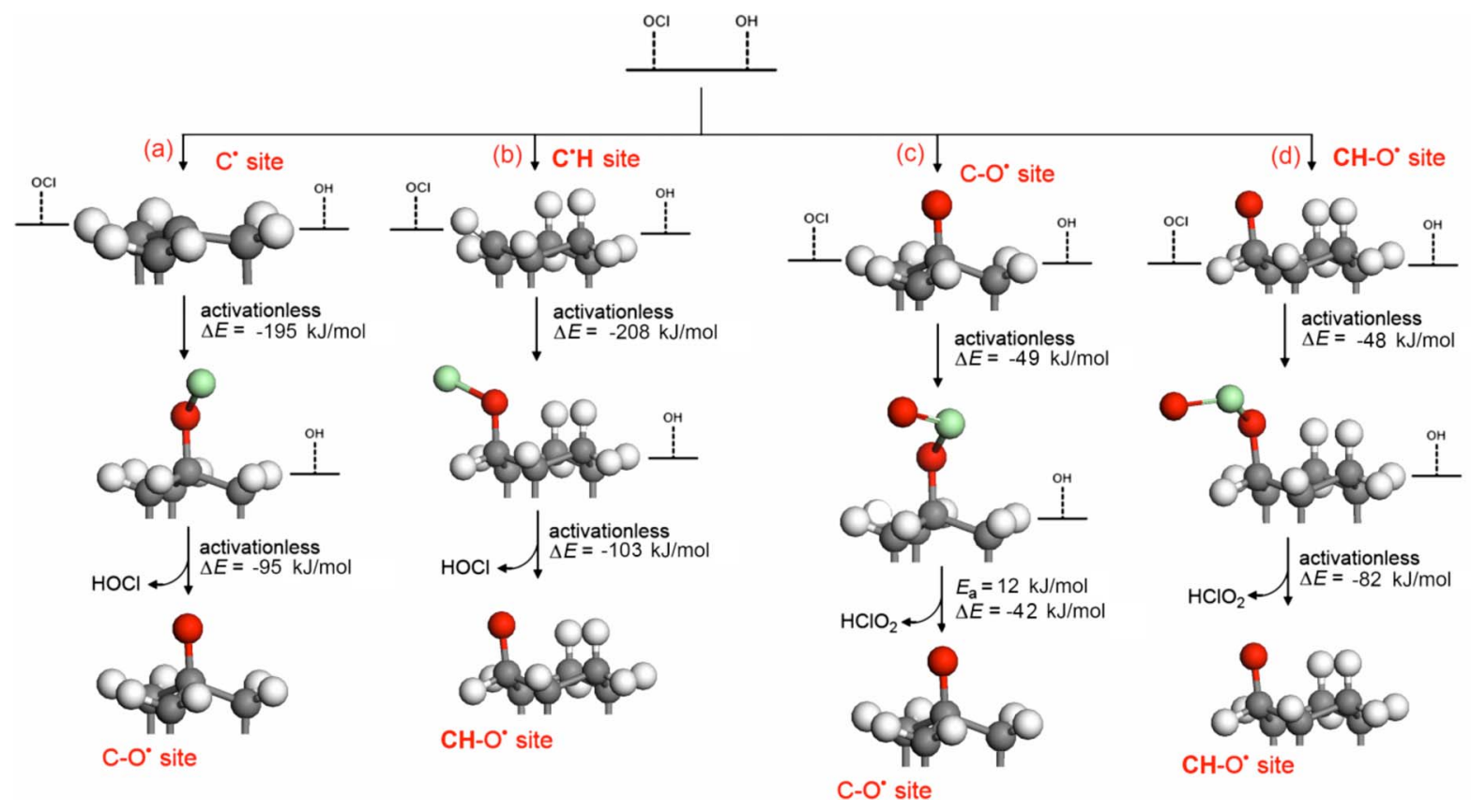

Figure 6. Scheme for $\mathrm{OCl}^{\bullet}$ interaction at oxidized diamond surface sites, including (a) $\equiv \mathrm{C}^{\bullet}$ site, $(\mathrm{b})=\mathrm{C}^{\bullet} \mathrm{H}$ site, (c) $\equiv \mathrm{C}-\mathrm{O}^{\bullet}$ site, and (d) $\equiv \mathrm{CH}-\mathrm{O}^{\bullet}$ site. Atom key for electronic version of manuscript: carbon, gray; hydrogen, white; oxygen, red; chlorine, green.

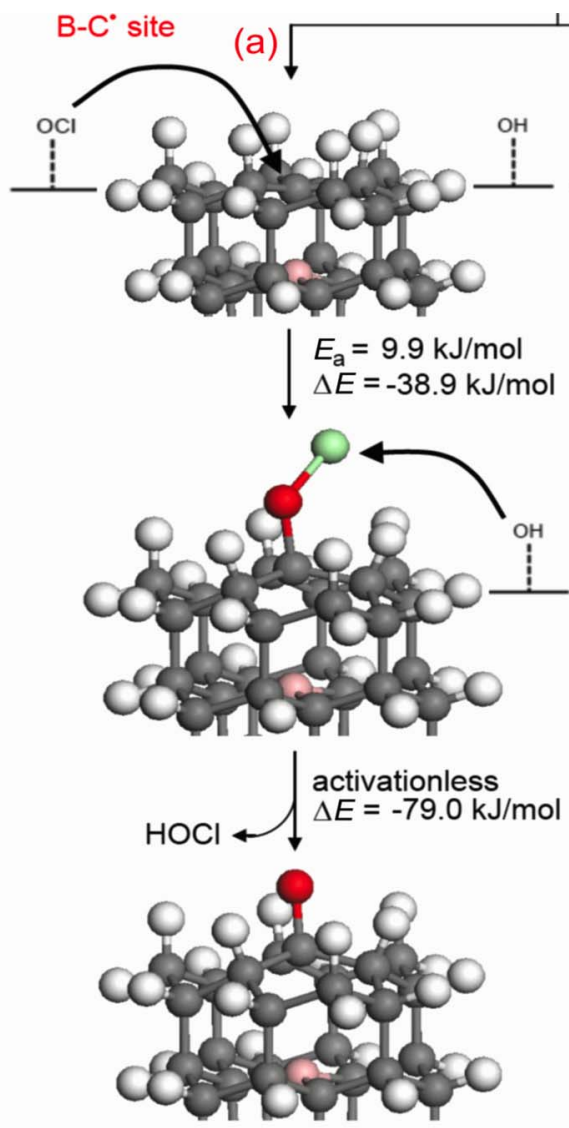

B-C-O* site
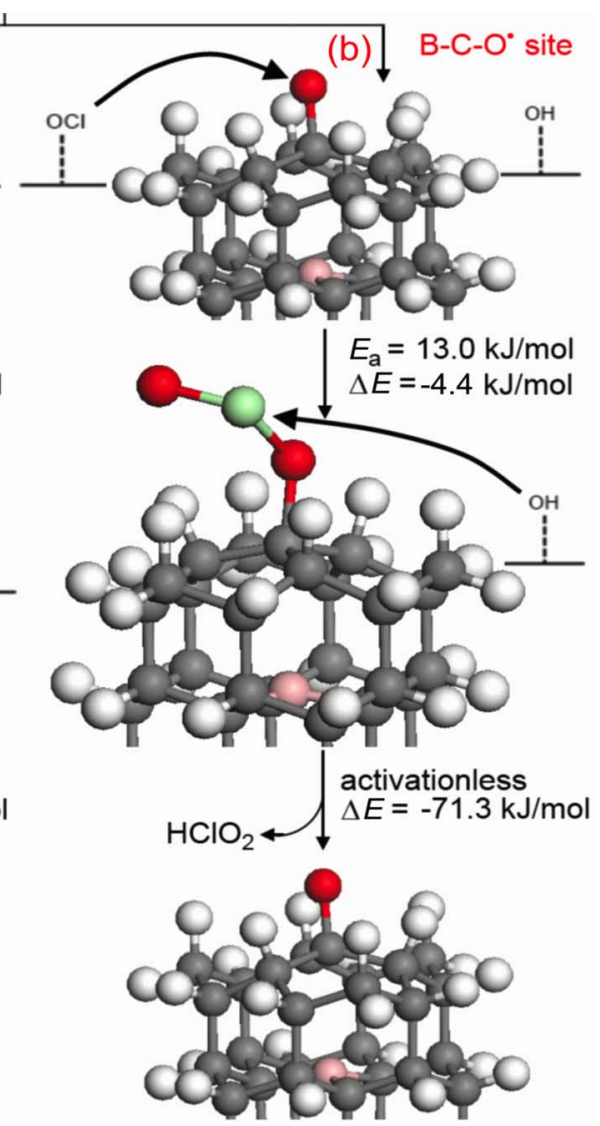

$\mathrm{B}-\mathrm{C}-\mathrm{O}^{\circ}$ site
Figure 7. Scheme for hypochlorite and chlorite generation at a boron-doped surface site. Atom key for electronic version of manuscript: carbon, gray; hydrogen, white; oxygen, red; chlorine, green; boron, pink. 
and an overall energy change of $\Delta E=-42 \mathrm{~kJ} / \mathrm{mol}$. This low activation energy indicates that this reaction could proceed at room temperatures.

Similarly, Figure 6d shows a two-step scheme for $\mathrm{HClO}_{2}$ production at the oxidized edge site:

$$
\begin{array}{r}
=\mathrm{CH}-\mathrm{O}^{\bullet}+\mathrm{OCl}^{\bullet} \rightarrow=\mathrm{CH}-\mathrm{O}-\mathrm{ClO} \\
=\mathrm{CH}-\mathrm{O}-\mathrm{ClO}+\mathrm{HO}^{\bullet} \rightarrow=\mathrm{CH}-\mathrm{O}^{\bullet}+\mathrm{HClO}_{2}
\end{array}
$$

Both steps are activationless, with $\Delta E=-48 \mathrm{~kJ} / \mathrm{mol}$ for reaction 11 and $\Delta E=-82 \mathrm{~kJ} / \mathrm{mol}$ for reaction 12 .

DFT calculations were also performed to investigate reactions between $\mathrm{OCl}^{\bullet}$ radicals and functional groups on the 34-carbon atom cluster shown in Figure 1b. Figure 7 a shows a two-step reaction scheme for the oxidation of a $\mathrm{B} \equiv \mathrm{C}^{\bullet}$ site in the presence of $\mathrm{OCl}^{\bullet}$ and $\mathrm{HO}^{\bullet}$ radicals

$$
\begin{gathered}
\mathrm{B} \equiv \mathrm{C}^{\bullet}+\mathrm{OCl}^{\bullet} \rightarrow \mathrm{B} \equiv \mathrm{C}-\mathrm{OCl} \\
\mathrm{B} \equiv \mathrm{C}-\mathrm{OCl}+\mathrm{HO}^{\bullet} \rightarrow \mathrm{B} \equiv \mathrm{C}-\mathrm{O}^{\bullet}+\mathrm{HOCl}
\end{gathered}
$$

Reaction 13 has an activation energy of $9.9 \mathrm{~kJ} / \mathrm{mol}$, with $\Delta E$ $=-38.9 \mathrm{~kJ} / \mathrm{mol}$ and reaction 14 is activationless with $\Delta E=-79 \mathrm{~kJ} / \mathrm{mol}$.

Reactions at the $\mathrm{B} \equiv \mathrm{C}-\mathrm{O}^{\bullet}$ sites were also investigated to determine if they also catalyzed $\mathrm{HClO}_{2}$ production. Figure $7 \mathrm{~b}$ shows a two-step reaction scheme for $\mathrm{HClO}_{2}$ production at a $\mathrm{B} \equiv \mathrm{C}-\mathrm{O}^{\bullet}$ site:

$$
\begin{gathered}
\mathrm{B} \equiv \mathrm{C}-\mathrm{O}^{\bullet}+\mathrm{OCl}^{\bullet} \rightarrow \mathrm{B} \equiv \mathrm{C}-\mathrm{O}-\mathrm{ClO} \\
\mathrm{B} \equiv \mathrm{C}-\mathrm{O}-\mathrm{ClO}+\mathrm{HO}^{\bullet} \rightarrow \mathrm{B} \equiv \mathrm{C}-\mathrm{O}^{\bullet}+\mathrm{HClO}_{2}
\end{gathered}
$$

The chemisorption reaction has an activation energy of $13 \mathrm{~kJ} / \mathrm{mol}$ with an energy change of $\Delta E=-49 \mathrm{~kJ} / \mathrm{mol}$ for reaction 15 . The subsequent oxidation step (reaction 16) is activationless and an overall energy change of $\Delta E=-71.3 \mathrm{~kJ} / \mathrm{mol}$.

The contrast between the boron-doped sites $\left(\mathrm{B} \equiv \mathrm{C}^{\bullet}\right.$ and $\left.\mathrm{B} \equiv \mathrm{C}-\mathrm{O}^{\bullet}\right)$ and bulk surface sites $\left(\equiv \mathrm{C}^{\bullet}\right.$ and $\left.\equiv \mathrm{C}-\mathrm{O}^{\bullet}\right)$ in energy change and activation energy demonstrates an important feature of the radical carbon site above the boron atom, which we term the "trampoline" carbon. When bonded to only the three neighboring carbons, the trampoline carbon retreats into the cluster, borrowing electron density from the boron atom. Thus, the energy change for chemisorption in Figure $7 \mathrm{a}$ is less negative at the trampoline carbon than bulk surface sites, shown in Figure 6a and 6b. However, the trampoline carbon can also extend toward the surface to stabilize other radical species in solution. In this case, the boron atom withdraws electron density from the carbon radical surface atom, likely creating the activation energy for adsorption of the $\mathrm{OCl}^{\bullet}$ radicals at the $\mathrm{B} \equiv \mathrm{C}^{\bullet}$ and $\mathrm{B} \equiv \mathrm{C}-\mathrm{O}^{\bullet}$ sites, compared to activationless adsorption at the $\equiv \mathrm{C}^{\bullet}$ and $\equiv \mathrm{C}-\mathrm{O}^{\bullet}$ sites.

These results indicate that oxygen radical sites act catalytically in producing $\mathrm{HClO}_{2}$. These oxygenated sites may be generated by reaction with $\mathrm{OCl}^{\bullet}$ radicals, in which the oxygen atom attacks a carbon radical surface site, as shown in Figure $6 a-6 b$ and Figure $7 a$, or via oxidation by $\mathrm{HO}^{\bullet}$ produced from water oxidation. ${ }^{19}$ Carbon radical surface sites do not interact with the chlorine atoms of $\mathrm{OCl}^{\bullet}$ radicals. The abundance of pathways that are activationless or require low activation energies, as summarized in Figure 6 and Figure 7, suggest that the surface may be involved in $\mathrm{HClO}_{2}$ production by chemisorbing radical species, stabilizing them and giving them a longer life-time to subsequently react with $\mathrm{HO}^{\bullet}$ to form $\mathrm{HClO}_{2}$.

Chlorate formation.- - Figure 8 shows CV scans with varying concentrations of $\mathrm{NaClO}_{2}$ in a $100 \mathrm{mM} \mathrm{KH} \mathrm{PO}_{4}$ background electrolyte. Two distinct peaks are observed that increased upon increasing concentration of $\mathrm{NaClO}_{2}$. The first peak likely corresponds to the oxidation of $\mathrm{HClO}_{2}$ to $\mathrm{ClO}_{2}{ }^{\bullet}$. However, the second oxidation peak occurs at much higher potentials, where $\mathrm{HO}^{\bullet}$ are generated, and based on the position of the peak ( $\mathrm{E} \sim 2.5 \mathrm{~V} / \mathrm{SHE})$, it likely represents the oxidation of $\mathrm{HClO}_{3}$ to $\mathrm{ClO}_{3}{ }^{\bullet}$ (reaction 19). ${ }^{16}$ Batch oxidation experimental

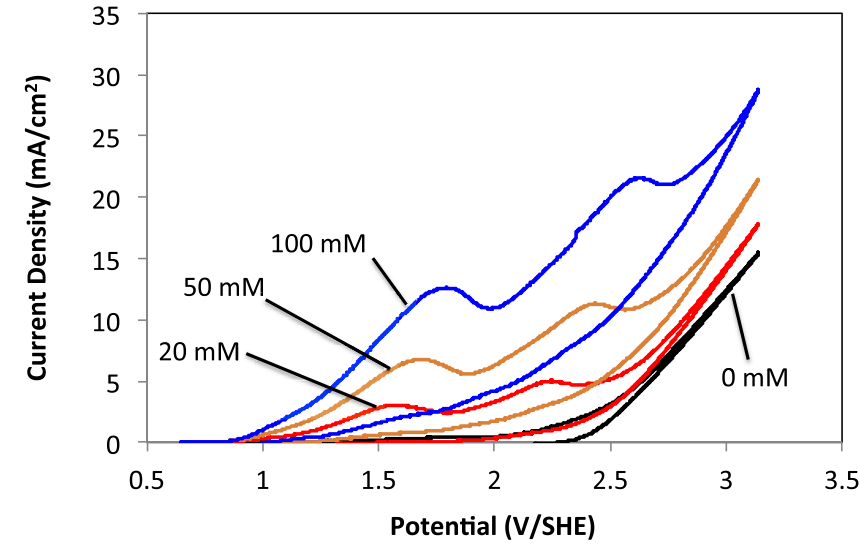

Figure 8. Polarization curves recorded during cyclic voltammetry on BDD in solutions with varying concentrations of $\mathrm{HClO}_{2}$. Electrolyte $=100 \mathrm{mM}$ $\mathrm{KH}_{2} \mathrm{PO}_{4}, \mathrm{pH} 4.6$.

data indicated that the oxidation of $\mathrm{ClO}_{2}{ }^{-}$at 1.64 and $2.64 \mathrm{~V} / \mathrm{SHE}$ resulted in only $\mathrm{ClO}_{3}{ }^{-}$production and other products were not detected in solution. Although the oxidation of $\mathrm{ClO}_{3}{ }^{-}$to $\mathrm{ClO}_{4}{ }^{-}$is thermodynamically favorable at these potentials, reported rates for $\mathrm{ClO}_{3}{ }^{-}$ oxidation are an order of magnitude slower than oxidation rates for $\mathrm{ClO}_{2}{ }^{-}$oxidation shown in Figure $9,{ }^{16}$ which explains the lack of detectable $\mathrm{ClO}_{4}{ }^{-}$in solution. The experimentally determined activation energies for the oxidation of $\mathrm{ClO}_{2}{ }^{-}$to $\mathrm{ClO}_{3}{ }^{-}$were $34 \mathrm{~kJ} / \mathrm{mol}$ at 1.64 $\mathrm{V} / \mathrm{SHE}$ and $11 \mathrm{~kJ} / \mathrm{mol}$ at $2.64 \mathrm{~V} / \mathrm{SHE}$, as shown in the Arrhenius plot in Figure 9. Therefore, based on the $\mathrm{CV}$ and oxidation experiments, the following mechanism for $\mathrm{HClO}_{2}$ oxidation is proposed:

$$
\begin{gathered}
\mathrm{HClO}_{2} \rightarrow\left[\mathrm{HClO}_{2}\right]^{+}+\mathrm{e}^{-} \rightarrow \mathrm{ClO}_{2}{ }^{\bullet}+\mathrm{H}^{+}+\mathrm{e}^{-} \\
\mathrm{ClO}_{2}{ }^{\bullet}+\mathrm{HO}^{\bullet} \rightarrow \mathrm{HClO}_{3} \\
\mathrm{HClO}_{3} \rightarrow\left[\mathrm{HClO}_{3}\right]^{+}+\mathrm{e}^{-} \rightarrow \mathrm{ClO}_{3}{ }^{\bullet}+\mathrm{H}^{+}+\mathrm{e}^{-}
\end{gathered}
$$

DFT simulations were used to investigate reaction mechanisms for $\mathrm{ClO}_{3}{ }^{-}$and $\mathrm{HClO}_{3}$ production from $\mathrm{ClO}_{2}{ }^{-}$and $\mathrm{HClO}_{2}$. Since BDD anodes are known to generate $\mathrm{HO}^{\bullet}$ radicals, the reactions of $\mathrm{HO}^{\bullet}$ with $\mathrm{ClO}_{2}{ }^{-}$and $\mathrm{HClO}_{2}$ in homogeneous solution were considered. The $\mathrm{HClO}_{3}{ }^{-}$structure formed by reacting $\mathrm{HO}{ }^{\bullet}$ with $\mathrm{ClO}_{2}{ }^{-}$was found to be unstable, suggesting that this reaction does not occur. However, the reaction of $\mathrm{HO}^{*}$ with $\mathrm{HClO}_{2}$ was a route for activationless production of $\mathrm{ClO}_{2}{ }^{\bullet}$ species via reaction 20 :

$$
\mathrm{HClO}_{2}+\mathrm{HO}^{\bullet} \rightarrow \mathrm{ClO}_{2}^{\bullet}+\mathrm{H}_{2} \mathrm{O}
$$

The energy change for reaction 20 is $\Delta E=-21 \mathrm{~kJ} / \mathrm{mol}$.

The production of $\mathrm{ClO}_{2}{ }^{\bullet}$ may also occur via a direct electron transfer reaction between $\mathrm{HClO}_{2}$ and the electrode (reaction 17). Figure 10 shows the DFT calculated activation energy for $\mathrm{HClO}_{2}$

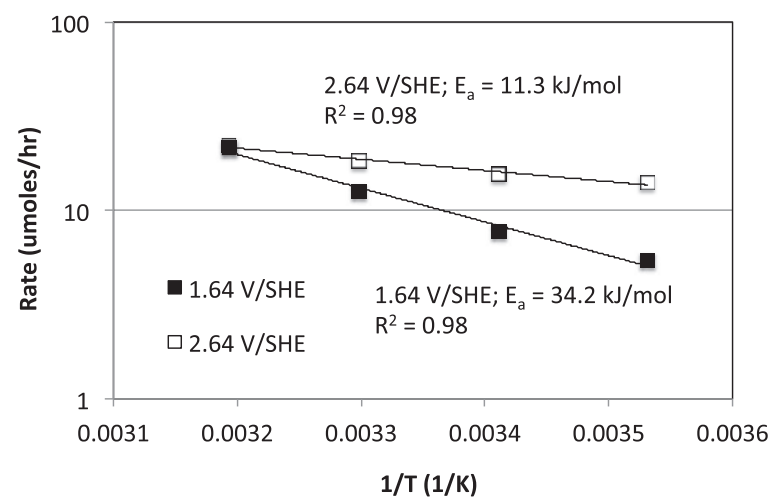

Figure 9. Arrhenius plots for the oxidation of $\mathrm{ClO}_{2}{ }^{-}$at 1.64 and $2.64 \mathrm{~V} / \mathrm{SHE}$. 


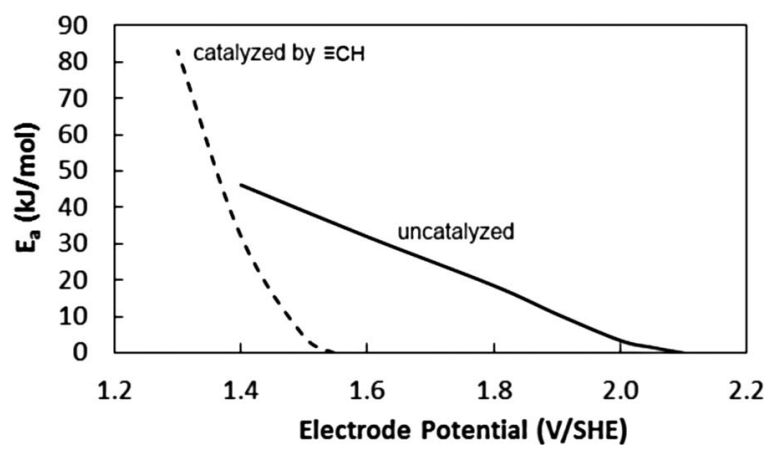

Figure 10. Activation energy as a function of electrode potential for oxidation of $\mathrm{HClO}_{2}$, shown in reaction 20 . The solid line corresponds to the uncatalyzed reaction; the dashed line corresponds to the reaction catalyzed by the BDD surface.

oxidation as a function of the electrode potential. Calculations indicated that the uncatalyzed reaction will begin to occur at measurable rates at potentials above $\sim 1.5 \mathrm{~V} / \mathrm{SHE}$, and becomes activationless at potentials above $2.10 \mathrm{~V} / \mathrm{SHE}$. The DFT calculations compared well with the experimentally measured activation energies (Figure 9), indicating that reaction 17 was likely the rate-determining step for $\mathrm{ClO}_{3}{ }^{-}$ production from $\mathrm{HClO}_{2}$. The DFT value was $29.3 \mathrm{~kJ} / \mathrm{mol}$ compared to the experimental value of $34.2 \mathrm{~kJ} / \mathrm{mol}$ at $1.64 \mathrm{~V} / \mathrm{SHE}$, and the DFT value was activationless compared to the experimental value of $11.3 \mathrm{~kJ} / \mathrm{mol}$ at $2.64 \mathrm{~V} / \mathrm{SHE}$. The low measured activation energy at $2.64 \mathrm{~V} / \mathrm{SHE}$ is in the range associated with activationless processes, ${ }^{34}$ and is likely a measure of temperature effects on the composition and thickness of the electrical double layer or the relative adsorption strengths of water, $\mathrm{HClO}_{2}$, or oxidation products on the BDD surface.

The CV scan shown in Figure 8 indicated that current began to flow at $\sim 1.0 \mathrm{~V} / \mathrm{SHE}$ upon $\mathrm{NaClO}_{2}$ addition to solution. The DFT calculations indicated that the activation energy for $\mathrm{HClO}_{2}$ oxidation at potentials of $\sim 1.0 \mathrm{~V} / \mathrm{SHE}$ are very high, which suggests that the BDD surface may catalyze this reaction. To investigate if surface sites have catalytic effects on $\mathrm{HClO}_{2}$ oxidation, the reaction was simulated near the $\mathrm{C}_{10} \mathrm{H}_{16}$ cluster, ${ }^{32}$ As shown in Figure 10, the potential for activationless electron transfer decreased from 2.10 V/SHE to $1.55 \mathrm{~V} / \mathrm{SHE}$, suggesting the $\mathrm{BDD}$ surface can catalyze $\mathrm{HClO}_{2}$ oxidation. However, the calculated activation energy at $\sim 1.0 \mathrm{~V} / \mathrm{SHE}$ is still exceedingly high to be a significant reaction pathway at $20^{\circ} \mathrm{C}$. Therefore, there may be other sites present on the BDD surface that are able to catalyze reaction 17 .

The oxidation of $\mathrm{ClO}_{2}{ }^{-}$rather than $\mathrm{HClO}_{2}$ is an alternate explanation for the increase in current beginning at $\sim 1 \mathrm{~V} / \mathrm{SHE}$. The electron transfer shown in reaction 21 was calculated to be activationless at $0 \mathrm{~V} / \mathrm{SHE}$

$$
\mathrm{ClO}_{2}^{-} \rightarrow \mathrm{ClO}_{2}{ }^{-}+\mathrm{e}^{-}
$$

The prevalence of this reaction compared to reaction 17 will depend on the $\mathrm{pH}$ adjacent to the electrode surface. That low reaction rates are seen until potentials significantly greater than $0 \mathrm{~V} / \mathrm{SHE}$ may result from the low concentration of $\mathrm{ClO}_{2}{ }^{-}$at the electrode surface. Although the $\mathrm{pKa}$ of $\mathrm{HClO}_{2}$ is 1.96 , the lower $\mathrm{pH}$ near the electrode surface versus the bulk solution will decrease the $\mathrm{ClO}_{2}{ }^{-}$concentration at the electrode surface.

DFT calculations were also performed to investigate if the $\mathrm{ClO}_{2}{ }^{\bullet}$ species generated in reactions 17 and 20 could react with $\mathrm{HO}^{\bullet}$ to form $\mathrm{HClO}_{3}$ (reaction 18). Modeling results determined that reaction 18 was activationless with an energy change of $\Delta E=-142 \mathrm{~kJ} / \mathrm{mol}$. These calculations suggest that a feasible pathway for $\mathrm{HClO}_{3}$ production from $\mathrm{HClO}_{2}$ is depicted in reactions 17, 18, and 20.

Interactions of the $\mathrm{ClO}_{2}{ }^{\bullet}$ species with the BDD surface were also considered. Figure 11 shows a scheme for $\mathrm{ClO}_{2}{ }^{\bullet}$ interactions with various BDD surface sites. Similar to the results for $\mathrm{OCl}^{\bullet}$ radicals, $\mathrm{ClO}_{2}{ }^{\bullet}$ radicals can undergo reactions at carbon radical sites on the surface, transforming them to oxygen radical sites. These oxygen radical sites can further mediate reactions between $\mathrm{ClO}_{2}{ }^{\bullet}$ and $\mathrm{HO}^{\bullet}$ to produce $\mathrm{HClO}_{3}$.

Figures $11 \mathrm{a}$ and $11 \mathrm{~b}$ show that $\mathrm{ClO}_{2}{ }^{\bullet}$ chemisorbs to two types of carbon radical sites on the diamond surface, according to the following reactions:

$$
\begin{gathered}
\equiv \mathrm{C}^{\bullet}+\mathrm{ClO}_{2}^{\bullet} \rightarrow \equiv \mathrm{C}-\mathrm{OClO} \\
=\mathrm{C}^{\bullet} \mathrm{H}+\mathrm{ClO}_{2}^{\bullet} \rightarrow=\mathrm{CH}-\mathrm{OClO}
\end{gathered}
$$

Reactions (22) and (23) are both activationless, with an overall energy change of $\Delta E=-144 \mathrm{~kJ} / \mathrm{mol}$ for reaction 22 , and $\Delta E$ $=-156 \mathrm{~kJ} / \mathrm{mol}$ for reaction (23). Each of these chemisorbed species

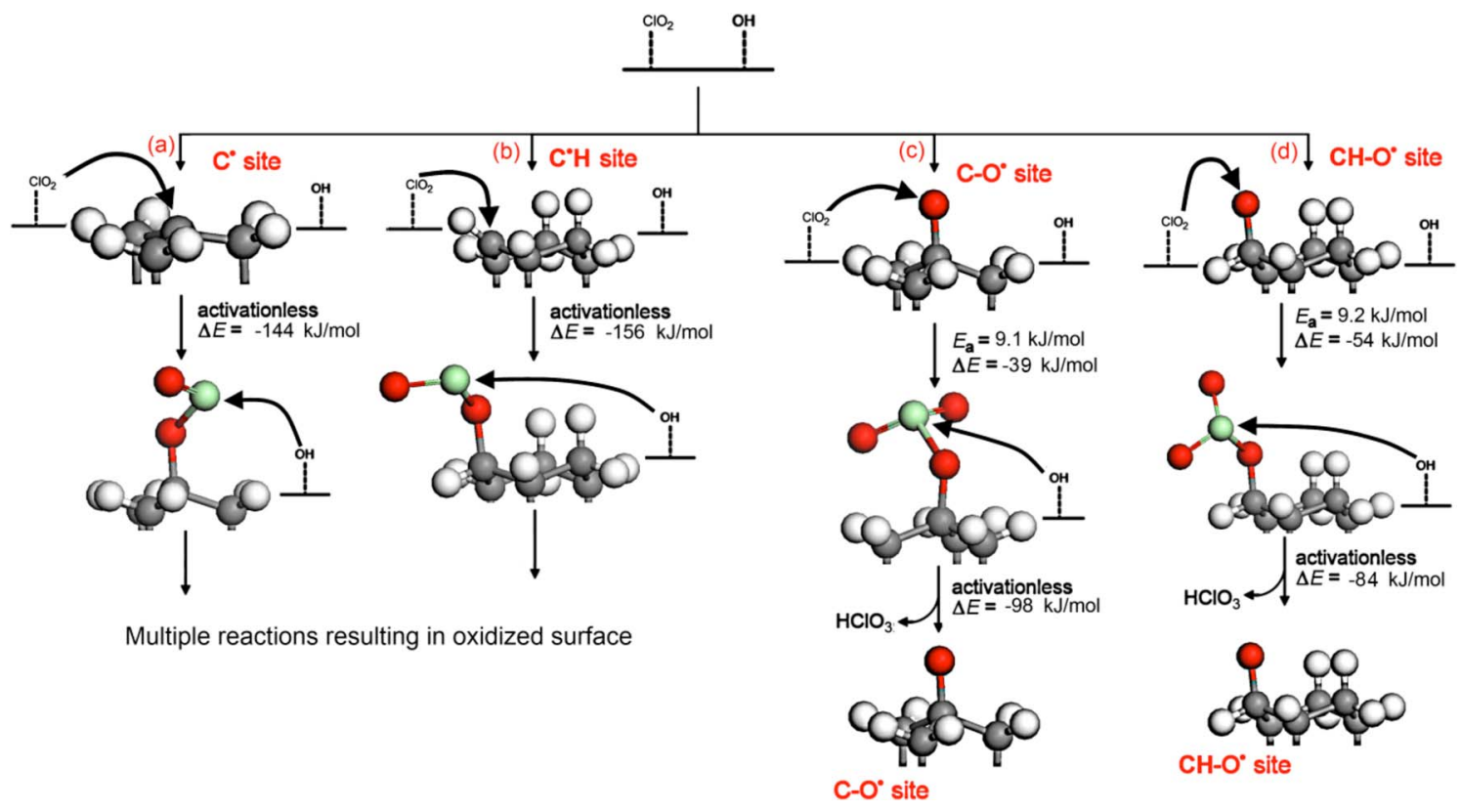

Figure 11. Scheme for $\mathrm{ClO}_{2}{ }^{\bullet}$ interaction with four sites on the bulk diamond surface: (a) $\equiv \mathrm{C}^{\bullet},(\mathrm{b})=\mathrm{C}^{\bullet} \mathrm{H},(\mathrm{c}) \equiv \mathrm{C}-\mathrm{O}^{\bullet}$, and $(\mathrm{d})=\mathrm{CH}-\mathrm{O}^{\bullet}$. Atom key for electronic version of manuscript: carbon, gray; hydrogen, white; oxygen, red; chlorine, green. 
are susceptible to $\mathrm{HO}^{\bullet}$ attack, producing the oxygen radical surface sites shown in Figure $11 \mathrm{c}$ and $11 \mathrm{~d}$. This attack regenerates the $\mathrm{HClO}_{2}$ molecule, similar to the case for $\mathrm{OCl}^{-}$discussed previously. The regenerated $\mathrm{HClO}_{2}$ molecule could continue to oxidize other surface atoms depending on the geometry of the product structure. While there may be multiple reactions, the resulting product always includes the oxidized surface.

The $\mathrm{ClO}_{2}{ }^{\bullet}$ radical also reacts with oxygen radical sites in the following reactions (Figure 11c and 11d):

$$
\begin{gathered}
\equiv \mathrm{C}-\mathrm{O}^{\bullet}+\mathrm{ClO}_{2}^{\bullet} \rightarrow=\mathrm{C}-\mathrm{O}-\mathrm{ClO}_{2} \\
=\mathrm{CH}-\mathrm{O}{ }^{\bullet}+\mathrm{ClO}_{2}^{\bullet} \rightarrow=\mathrm{CH}-\mathrm{O}-\mathrm{ClO}_{2}
\end{gathered}
$$

These reactions require an activation energy of $9.1 \mathrm{~kJ} / \mathrm{mol}$ for reaction 24 and $9.2 \mathrm{~kJ} / \mathrm{mol}$ for reaction 25 . The energy changes for these reactions are $\Delta E=-39 \mathrm{~kJ} / \mathrm{mol}$ for reaction 24 and $\Delta E=-54 \mathrm{~kJ} / \mathrm{mol}$ for reaction 25 . Each of these chemisorbed surface complexes may be attacked by $\mathrm{HO}^{\bullet}$ to yield $\mathrm{HClO}_{3}$. These reactions are shown below:

$$
\begin{aligned}
& \equiv \mathrm{C}-\mathrm{O}-\mathrm{ClO}_{2}+\mathrm{HO}^{\bullet} \rightarrow \equiv \mathrm{C}-\mathrm{O}^{\bullet}+\mathrm{HClO}_{3} \\
= & \mathrm{CH}-\mathrm{O}-\mathrm{ClO}_{2}+\mathrm{HO}^{\bullet} \rightarrow \equiv \mathrm{CH}-\mathrm{O}^{\bullet}+\mathrm{HClO}_{3}
\end{aligned}
$$

Both reactions are activationless, with $\Delta E=-98 \mathrm{~kJ} / \mathrm{mol}$ for reaction 26 , and $\Delta E=-83 \mathrm{~kJ} / \mathrm{mol}$ for reaction 27 .

A pathway to $\mathrm{HClO}_{3}$ production is also found at a boron-doped surface site and is shown in Figure 12. The two reactions, occurring

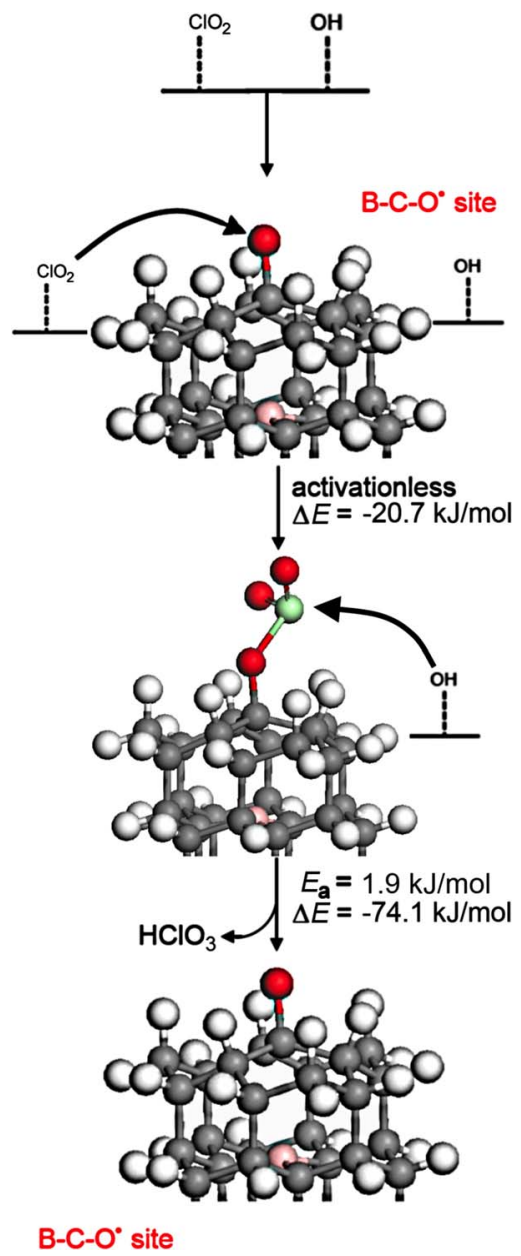

Figure 12. Scheme for $\mathrm{HClO}_{3}$ production at a $\mathrm{B} \equiv \mathrm{C}-\mathrm{O} \mathrm{O}^{\bullet}$ boron-doped site. Atom key for electronic version of manuscript: carbon, gray; hydrogen, white; oxygen, red; chlorine, green. in sequence, are

$$
\begin{array}{r}
\mathrm{B} \equiv \mathrm{C}-\mathrm{O}^{\bullet}+\mathrm{ClO}_{2}^{\bullet} \rightarrow \mathrm{B} \equiv \mathrm{C}-\mathrm{O}-\mathrm{ClO}_{2} \\
\mathrm{~B} \equiv \mathrm{C}-\mathrm{O}-\mathrm{ClO}_{2}+\mathrm{OH}^{\bullet} \rightarrow \mathrm{B} \equiv \mathrm{C}-\mathrm{O}^{\bullet}+\mathrm{HClO}_{3}
\end{array}
$$

The chemisorption step, reaction 28 , is activationless with $\Delta E$ $=-20.7 \mathrm{~kJ} / \mathrm{mol}$, and the subsequent oxidation step, reaction 29 , requires $1.9 \mathrm{~kJ} / \mathrm{mol}$ of activation energy, with $\Delta E=-74.1 \mathrm{~kJ} / \mathrm{mol}$.

Both the doped and undoped sites show low activation energy for formation of $\mathrm{HClO}_{3}$, with the chemisorption of $\mathrm{ClO}_{2}{ }^{\bullet}$ requiring activation at the undoped site, in contrast to the $\mathrm{OH}^{\bullet}$ attack at the doped site. The overall energy released, as well as activation energy for the rate-limiting step, is lower at the boron-doped site. This pattern is consistent with the calculations for formation of $\mathrm{HClO}_{2}$ at the "trampoline" carbon site, discussed above.

\section{Conclusions}

This article presents a plausible set of reaction pathways for producing chlorite and chlorate from hypochlorite using a BDD anode. Both protonated and unprotonated hypochlorite, chlorite and chlorate species can be oxidized to their respective radical, $\mathrm{ClO}_{\mathrm{x}}{ }^{\circ}$, at potentials below that for water oxidation. In addition, hypochlorous, chlorous and chloric acids can be oxidized by $\mathrm{HO}^{\bullet}$ produced from water oxidation. The oxychlorine radical species may react with $\mathrm{HO}^{\bullet}$ in solution to form a more oxidized species, or may chemisorb to anodically generated $\equiv \mathrm{C}^{\bullet},=\mathrm{C}^{\bullet} \mathrm{H}, \equiv \mathrm{C}-\mathrm{O}^{\bullet}$, and $=\mathrm{CH}-\mathrm{O}^{\bullet}$ sites on the BDD surface. Chemisorption of the oxychlorine radicals stabilizes them and gives them a longer life-time to react. Both surface catalyzed and solution phase pathways for chlorite and chlorate production involve hydroxyl radicals. The greater production of hydroxyl radicals by BDD anodes, as compared to platinum and $\mathrm{RuO}_{2}$ coated anodes, likely explains the greater perchlorate generation observed with BDD anodes during electrochemical hypochlorite generation, ${ }^{10,35}$

\section{Acknowledgments}

Funding for this work was provided by the National Science Foundation (CBET-0931749).

\section{References}

1. H. B. Martin, A. Argoitia, U. Landau, A. B. Anderson, and J. C. Angus, Journal of the Electrochemical Society, 143, L133 (1996).

2. K. E. Carter and J. Farrell, Environ. Sci. Technol., 42, 6111 (2008),

3. B. P. Chaplin, Critical Review of Electrochemical Advanced Oxidation Processes for Water Treatment Applications, Environ. Sci.: Processes Impacts DOI: 10.1039/C3EM00679D (2014).

4. B. P. Chaplin, G. Schrader, and J. Farrell, Environmental Science \& Technology, 43(21), 8302 (2009).

5. B. P. Chaplin, G. Schrader, and J. Farrell, Environ. Sci. Technol., 44, 4264 (2010).

6. M. J. Pacheco, V. Santos, L. Ciriaco, and A. Lopes, Journal of Hazardous Materials, 186, 1033 (2011).

7. J. F. Zhi, H. B. Wang, T. Nakashima, T. N. Rao, and A. Fujishima, J. Phys. Chem. B, 107, 13389 (2003).

8. M. E. H. Bergmann, in: Electrochemistry for the Environment, C. Comninellis and G. Chen, Editors, p. 163, Springer (2009).

9. M. E. H. Bergmann and J. Rollin, Catalysis Today, 124, 198 (2007).

10. M. E. H. Bergmann, J. Rollin, and T. Iourtchouk, Electrochimica Acta, 54, 2102 (2009).

11. E. Urbansky, Environmental Science and Pollution Research, 9, 187 (2002).

12. E. T. Urbansky and M. R. Schock, Journal of Environmental Management, 56, 79 (1999).

13. Interim Drinking Water Health Advisory for perchlorate EPA 822-R-08-025.; U. S. EPA: Washington, D., Dec 2008, Eds.

14. Perchlorate fact sheet for public water suppliers in: M. D.o.E. Protection, (Ed.), Boston, MA, 2006.

15. Perchlorate in drinking water, in: C. D. o. H. Services, (Ed.), Sacramento, CA, 2006

16. O. Azizi, D. Hubler, G. Schrader, J. Farrell, and B. P. Chaplin, Environ. Sci. Technol., 45, 10582 (2011).

17. D. Mishra, Z. H. Liao, and J. Farrell, Environ. Sci. Technol., 42, 9344 (2008),

18. Y. Cai, A. B. Anderson, J. C. Angus, and L. N. Kostadinov, Journal of the Electrochemical Society, 154, F36 (2007).

19. B. P. Chaplin, D. K. Hubler, and J. Farrell, Electrochimica Acta, 89, 122 (2013). 
20. H. Girard, N. Simon, D. Ballutaud, M. Herlem, and A. Etcheberry, Diamond and Related Materials, 16, 316 (2007).

21. K. B. Holt, A. J. Bard, Y. Show, and G. M. Swain, Journal of Physical Chemistry B, 108, 15117 (2004).

22. J. Xu, M. C. Granger, Q. Chen, J. W. Strojek, T. E. Lister, and G. M. Swain, Anal. Chem., 69, 591A (1997).

23. Materials Studio, v.4.2; Accelrys Corporation: San Diego, CA.

24. B. Delley, J. Chem. Phys., 92, 508 (1990).

25. B. Delley, J. Chem. Phys., 113, 7756 (2000).

26. A. D. Becke, Physical Review A, 38, 3098 (1988).
27. B. Delley, J. Phys. Chem., 100, 6107 (1996)

28. C. T. Lee, W. T. Yang, and R. G. Parr, Physical Review B, 37, 785 (1988)

29. B. Delley, Physical Review B, 66, 155125 (2002).

30. B. Delley, Mol. Simulat., 32, 117 (2006).

31. S. P. de Visser, Journal of Biocatalysis and Biotransformation, 1 (2012).

32. A. B. Anderson and D. B. Kang, Journal of Physical Chemistry A, 102, 5993 (1998).

33. C. P. Kelly, C. J. Cramer, and D. G. Truhlar, J. Phys. Chem. A, 110, 2493 (2006).

34. J. M. Smith, Chemical Engineering Kinetics; McGraw-Hill: New York (1980).

35. A. Kraft, Platinum Metals Review, 52, 177 (2008). 